\title{
Scheelite weathering and tungsten (W) mobility in historical oxidic-sulfidic skarn tailings at Yxsjöberg, Sweden
}

\author{
Lina P.B. Hällström ${ }^{1}$ (D) - Lena Alakangas ${ }^{1}$ - Olof Martinsson ${ }^{2}$ \\ Received: 4 March 2019 / Accepted: 5 December 2019 / Published online: 21 December 2019 \\ (C) The Author(s) 2019
}

\begin{abstract}
More knowledge of the geochemical behavior of tungsten (W) and associated contamination risks is needed. Therefore, weathering of scheelite $\left(\mathrm{CaWO}_{4}\right)$ and secondary sequestration and transport of $\mathrm{W}$ to groundwater in historical skarn tailings and surface water downstream of the tailings were studied. The tailings contained $920 \mathrm{mg} / \mathrm{kg} \mathrm{W}$, primarily in scheelite. Mineralogical and geochemical analyses were combined to elucidate the geochemical behavior of $\mathrm{W}$ in the tailings, and water samples were taken monthly during 2018 to monitor its mobility. In the tailings, a large peak of W was found at $1.5 \mathrm{~m}$ depth. There, $30 \mathrm{wt} \%$. of $\mathrm{W}$ was present in easily reducible phases, indicating former scheelite weathering. Currently, $\mathrm{W}$ is being released from scheelite to water-soluble phases at $2.5 \mathrm{~m}$ depth. The release of $\mathrm{WO}_{4}{ }^{2-}$ is hypothetically attributed to anion exchange with $\mathrm{CO}_{3}{ }^{2-}$ released from calcite neutralizing acid produced from pyrrhotite oxidation in the upper tailings and transported downwards to $\mathrm{pH}$ conditions $>7$. Higher concentrations of dissolved $\mathrm{W}$ were found in the groundwater and particulate $\mathrm{W}$ in downstream surface water than in reference water, but they were lower than current contamination thresholds. Tungsten showed correlations with hydrous ferric oxides (HFO) in both the tailings and surface water.
\end{abstract}

Keywords Skarn tailings $\cdot$ Scheelite weathering $\cdot$ Tungsten mobility $\cdot$ Carbonate exchange $\cdot$ Hydrous ferric oxides $\cdot$ Goethite

\section{Introduction}

In recent decades, concerns regarding elevated concentrations of tungsten $(\mathrm{W})$ in the terrestrial environment have been raised (Cui and Johannesson 2017; Datta et al. 2017; Koutsospyros et al. 2006; Lemus and Venezia 2015; Strigul 2010; Zoroddu et al. 2018, and references therein). High concentrations combined with poor knowledge of its geochemical behavior and toxicity has led to the US Environmental Protection Agency (2014) classifying $\mathrm{W}$ as an emerging contaminant of concern, and in Russia it was classified as a highly dangerous contaminant in aquatic systems in 2009 (Strigul et al. 2009). Tungsten has previously been considered an immobile metal and therefore has not been expected to have adverse environmental or toxicological effects

Responsible editor: Philippe Garrigues

Lina P.B. Hällström

Lina.Hallstrom@1tu.se

1 Applied Geochemistry, Luleå University of Technology, Luleå, Sweden

2 Ore Geology, Luleå University of Technology, Luleå, Sweden
(Strigul 2010). However, recently published reports describe elevated $\mathrm{W}$ concentrations in ground and surface water (Candeias et al. 2015; Gurbanov et al. 2015; Mohajerin et al. 2014; Johannesson et al. 2013; Seiler et al. 2005), bioaccumulation in higher trophic levels of ecosystems (Kennedy et al. 2012; Lin et al. 2014; Lindsay et al. 2017; Wilson and Pyatt 2006; Wilson and Pyatt 2009), and adverse effects on plants, fishes, and other organisms (Strigul et al. 2005; Strigul et al. 2010; Strigul 2010). The geochemical behavior of $\mathrm{W}$ is still not fully understood and research on its mobility is needed. What is known is that $\mathrm{W}$ belongs to group 6 of the periodic table, and has similar behavior to Mo (Gustafsson 2003; Kashiwabara et al. 2013; Kreissl et al. 2016). It forms monometric tungstate $\left(\mathrm{WO}_{4}{ }^{2-}\right)$ in natural waters with near-neutral or alkaline $\mathrm{pH}$ and can form several polyoxyanionic species in acidic waters (Koutsospyros et al. 2006). Tungsten has high affinity for hydrous ferric oxides (HFO) at $\mathrm{pH}$ conditions below 8 (Gustafsson 2003; Kashiwabara et al. 2013; Kreissl et al. 2016) and its adsorption to and/or co-precipitation with ferrihydrite and goethite are believed to be strong scavenging processes in the environment (Cui and Johannesson 2017; Kashiwabara et al. 2013).

Elevated concentrations of $\mathrm{W}$ have been found downstream of W-rich ore deposits and mining areas (Candeias 
et al. 2015; Lin et al. 2014; Gurbanov et al. 2015; Petta et al. 2014; Seiler et al. 2005; Wilson and Pyatt 2006; Wilson and Pyatt 2009), but associated W releases have been poorly studied. More than $50 \%$ of $\mathrm{W}$ in primary minerals is found as scheelite in skarn ore deposits (Kwak 2012; Ray et al. 1995; Werner et al. 1998) and in historical times more than thirty scheelite skarn deposits have been mined at large scale (Kwak 2012; Meinert 1992; Werner et al. 1998). Historical tailings might pose higher risks of $\mathrm{W}$ contamination than active mines, due to careless disposal and high $\mathrm{W}$ contents resulting from inefficient extraction techniques (Gao et al. 2016; Hällström et al. 2018a; Marinakis and Kelsall 1987). Furthermore, release of $\mathrm{W}$ from scheelite may be promoted in skarn tailings by the high abundance of carbonates. Thus, several laboratory studies have detected release of $\mathrm{W}$ from scheelite in groundwater with near-neutral $\mathrm{pH}$ conditions, and hypothetically attributed it to anion exchange with $\mathrm{CO}_{3}{ }^{2-}$ (Atademir et al. 1979; Marinakis and Kelsall 1987; Montgomery and McKibben 2012). Accordingly, in historical skarn tailings at Yxsjöberg in Sweden, Hällström et al. (2018a, 2018b) found indications of scheelite weathering and $\mathrm{W}$ release. Moreover, monitoring by the local municipality detected $\mathrm{W}$ in groundwater, freshwater, and sediments as far as $5 \mathrm{~km}$ from the mining area (Höglund et al. 2004; Höglund et al. 2005). Thus, in this study, geochemical and mineralogical analyses were combined to seize the opportunity to study the weathering of scheelite, secondary sequestration of $\mathrm{W}$ in the tailings, and the transport of $\mathrm{W}$ to receiving groundwater and downstream surface waters at Yxsjöberg.

\section{Study area}

In the Smaltjärnen repository, 2.8 million tons of tailings from the closed $\mathrm{W}, \mathrm{Cu}$, and fluorite mine at Yxsjöberg, Sweden (1918-1989) have been stored for more than 50 years. Detailed information about the site is presented by Hällström et al. (2018a). The tailings were deposited in the Smaltjärnen Repository during two active mining periods: 1918-1920 and 1935-1963 (Fig. 1). The Smaltjärnen repository area consisted of bogs and swamps, and no dams controlled the deposition of the tailings (Rothelius 1957). Lake Smaltjärnen is located directly south of the repository and people live in the vicinity of the tailings. In the repository, average contents of $\mathrm{Be}, \mathrm{Bi}, \mathrm{Cu}, \mathrm{Sn}, \mathrm{W}, \mathrm{Zn}, \mathrm{F}$, and $\mathrm{S}$ in the tailings are 284, 495, 946, 559, 960, and $301 \mathrm{ppm}$ and 1.9 and $1.2 \mathrm{wt} \%$, respectively, according to analyses of 99 samples. Ca-rich silicates constitute $87.5 \mathrm{wt} \%$ of the tailings, and minerals including fluorite, calcite, pyrrhotite, pyrite, chalcopyrite, scheelite, bismuthinite, cassiterite, danalite, and magnetite are also abundant (Hällström et al. 2018a). Between 1969 and 1989, tailings were deposited in Morkulltjärnen Repository in the north (Fig. 1). Unlike Smaltjärnen, Morkulltjärnen is controlled by dams, covered by vegetation and partly saturated (Höglund et al. 2004).

\section{Materials and methods}

\section{Field sampling}

A representative core $(\mathrm{P} 4)$ of four sampled by Hällström et al. (2018a) was chosen for a detailed study (Fig. 1). The intact vertical core reached a depth of $7.5 \mathrm{~m}$ and was taken in a Plexiglas tube (Ø 2", $1.2 \mathrm{~m}$ each) and divided into 36 subsamples, 10-15 cm thick each. The samples were stored in cool and dark conditions in diffusion-tight bags, then analyzed by an accredited laboratory (ALS Minerals) for total concentrations of 66 elements. For detailed descriptions of the analytical methodology, standard reference materials, and detection limits, see Hällström et al. (2018a). As illustrated in Fig. 1, a groundwater pipe (P7) was installed in the tailings downstream of $\mathrm{P} 4$.

\section{Environmental mineralogy}

Polished uncovered thin sections of 11 subsamples of $\mathrm{P} 4$ were examined, in duplicate, with transmitted and reflected light optical microscopy, using an Eclipse LV100POL instrument (Nikon). A modified alteration index (AI) method similar to those by Moncur et al. (2009) and Blowes and Jambor (1990) were used on the minerals in the thin sections of $\mathrm{P} 4$ to distinguish between oxidized and unoxidized environments in the tailings core. The AI classified unaltered pyrrhotite and calcite as 0 and completely altered/depleted minerals as 10 . The extent of secondary formations of HFO was also taken into account as an indicator of an oxidized environment. The absences of HFO were classified as 0 and high abundance was classified as 10 .

Mineral grains and rims of interest in the thin sections were examined by scanning electron microscopy (SEM) with energy dispersive X-ray spectroscopy (EDS) using a highresolution Zeiss Merlin ${ }^{\text {TM }}$ FE-SEM $(10 \mathrm{KeV}$ and $1 \mu \mathrm{A})$ system and Aztec Software from Oxford Instruments. Raman vibrational spectroscopy was used on chosen thin sections from $3.6 \mathrm{~m}$ depth to determine the HFO around scheelite, pyrrhotite, and magnetite. Measurements with a green laser $(532 \mathrm{~nm})$ were acquired with a Bruker Raman Scope, Olympus BX51 microscope, and OPUS 7 Senterra software. Scheelite was measured with $10 \mathrm{~mW}, 5 \mathrm{~s}$ and 5 repetitions, and HFO around scheelite, magnetite, and pyrrhotite were measured with $0.2 \mathrm{~mW}, 1 \mathrm{~s}$ and 10 repetitions. Precautions using low laser power measurements were taken to avoid mineral transformation. 
Fig. 1 The map shows the localization of a) Yxsjöberg mining area in Sweden, b) the water samples (red dots) taken in the surface water downstream the two tailings repositories (Smaltjärnen and Morkulltjärnen) and the reference point, and c) the intact tailings core (grey dot: P4) and the groundwater samples (red dot: P7) in Smaltjärnen

Repository. The arrows shows the water flow direction

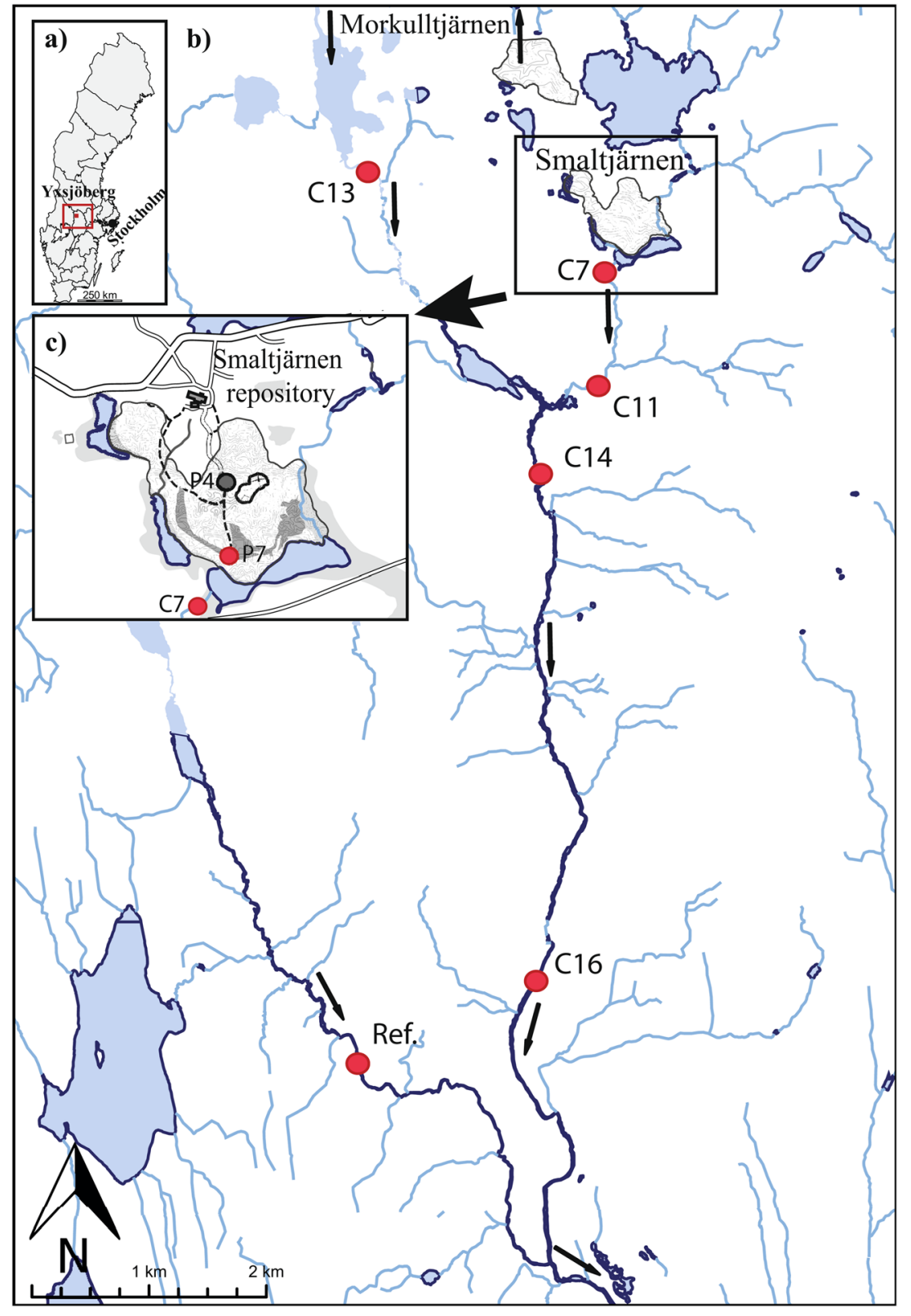

\section{7-step sequential extraction}

Five samples from P4 were sent to SGS Canada Inc. (Lakefield, ON, Canada) for 7-step sequential extraction according to Dold (2003). This procedure is intended to extract: (1) water-soluble phase, (2) exchangeable phase, (3) easily reducible minerals (e.g., oxyhydroxides), (4) resistant reducible minerals (e.g., magnetite), (5) easily oxidizable minerals (e.g., secondary sulfides), (6) resistant oxidizable minerals (e.g., primary sulfides), and (7) residues and silicates. The concentrations of 35 elements in each eluate were analyzed with inductively coupled plasma optical emission spectrometry (ICP-OES) and converted into $\mathrm{mg} / \mathrm{kg}$ released from the tailings. The detection limit for elements extracted in each step was $10 \mathrm{mg} / \mathrm{kg}$. Total concentrations in the tailings were determined by inductively coupled plasma atomic emission spectroscopy (ICP-AES) and inductively coupled plasma mass spectrometry (ICP-MS) after digestion via sodium peroxides fusion in graphite crucibles.

\section{Groundwater and surface water sampling}

Groundwater in the tailings and surface water downstream of the tailings were sampled monthly during May to October in 2018. Groundwater was pumped using a portable Masterflex ${ }^{\circledR}$ peristaltic pump (Cole-Parmer ${ }^{\circledR}$ International, Chicago, IL, USA) connected to a silicon tube $(9 \mathrm{~mm})$ at one pipe (P7) (Fig. 1). The water was pumped for 10-15 
min to remove stagnant groundwater before determination of $\mathrm{pH}$, electrical conductivity (EC), and temperature. The $\mathrm{O}_{2^{-}}$ concentration was measured during sampling in October with an $\mathrm{O}_{2}$-meter. To avoid oxygenation of the groundwater, the tube was connected directly to a vacuum Sterifil@ Aseptic System and Holder from Merck Millipore with a 42-mm diameter. The water was filtered directly in dark conditions to avoid precipitation of hydrous ferric oxides on the filters.

Surface water was sampled at five sampling points in the catchment area of Smaltjärnen and Morkulltjärnen (designated C7, 11, 13, 14, and 16), as well as a reference point (Ref.) in a neighboring catchment (Fig. 1). Points C7 and C11 were located downstream of Smaltjärnen, while C13 was downstream of Morkulltjärnen. Waters from Smaltjärnen and Morkulltjärnen comingle upstream before reaching sampling points $\mathrm{C} 14$ and $\mathrm{C} 16$. The surface water was pumped on-line through 142-mm-diameter polycarbonate and acrylic filter holders supplied by Geoteck Environmental Equipment Inc. (Denver, CO, USA). Both groundwater and surface water samples were filtered using $0.22-\mu \mathrm{m}$ cellulose acetate membrane filters that had been washed with $5 \%$ acetic acid for $72 \mathrm{~h}$ and rinsed with milliQ water for $24 \mathrm{~h}$ (Odman et al. 1999). Screening analyses of 71 elements in the filtered groundwater and surface water (dissolved phase) were carried out by ALS Scandinavia, using inductively coupled plasma sector field mass spectrometry (ICP-SFMS), while sulfate and fluoride were analyzed by ion chromatography (CSN ISO 10304-1, CSN EN 16192). All analyses were carried out in duplicate, with appropriate blanks and standards for quality control. In all cases, the samples were not acidified in the field, which could enhance insoluble tungstic acid formation (Bednar et al. 2010), and the samples were analyzed as soon as possible to prevent $\mathrm{W}$ from sticking to the vessel walls (Gustafsson 2003). Particulate phases trapped on the filters used in the surface water filtration were analyzed following the same procedure as the dissolved phase by ALS Scandinavia after lithium metaborate and $\mathrm{HNO}_{3} / \mathrm{HF} / \mathrm{HCl}$ digestion.

The filter holders were cleaned with $5 \% \mathrm{HNO}_{3}$ between each sampling occasion, and blanks were obtained after the cleaning process for controls. Each filter holder was used solely for samples collected from a specific sampling location. New silicon tubes were used each time, and samples were taken from lower to higher concentrations to minimize cross-contamination.

\section{Results}

\section{Geochemical conditions in P4}

Two distinct sections were found in the P4 core based on the minerals' alteration indices and measurements of $\mathrm{pH}$ and $\mathrm{EC}$ in the tailings, indicating two periods of deposition (Fig. 2).
The upper section (section 1) extended from the ground surface down to $3.5 \mathrm{~m}$, and the lower section (section 2 ) from 3.5 to $6 \mathrm{~m}$.

The upper section contained an oxidized acidic zone $(\mathrm{pH}<$ 5.5), a transition zone with intermediate $\mathrm{pH}$ (5.5-7), and an unoxidized zone with near-neutral $\mathrm{pH}(>7)$. The oxidized acidic zone occurred between the ground surface and $1.5 \mathrm{~m}$ depth. The alteration indices indicated a strongly oxidizing environment in this section, with pyrrhotite completely replaced by HFOs $(\mathrm{AI}=9)$, depleted calcite $(\mathrm{AI}=10)$ and amorphous HFO present, mainly in rims around all grains (AI = 4-6) (Fig. 2). Scheelite grains with a yellow rim were occasionally found at this depth. The transition zone was between 1.5 and $2.5 \mathrm{~m}$ depth, with partly oxidized pyrrhotite, partly weathered calcite, and lower abundance of HFO (AI values: 2, 2, and 1 respectively). The unoxidized zone was between 2.5 and $3.5 \mathrm{~m}$, with intact pyrrhotite and calcite, and low abundance of HFO. At this depth, secondary precipitated orthogonal calcite was found frequently (Hällström et al. 2018a).

In the deeper tailings (section 2), another oxidized environment was distinguished by the AI values, at $3.6 \mathrm{~m}$ depth (Fig. 2). Pyrrhotite and calcite were partly weathered, and crystalline HFO was present as rims on pyrrhotite, magnetite, and scheelite grains (Figs. 2 and 3). Hydrous ferric oxides were not observed to the same extent on larger scheelite grains. The rims of HFO around the smaller scheelite grains were up to $30 \mu \mathrm{m}$ thick and surrounded parts of or the whole grains. Reflected light optical microscopy and SEM-EDS measurements showed that boundaries between scheelite and HFO were sharp, while those between HFO and pyrrhotite/ magnetite were inter-grown. Raman spectroscopic analyses of unweathered scheelite detected clear Raman bands at 82, $112,207,333,367,388,430,694,803,832$, and $909 \mathrm{~cm}^{-1}$ (Fig. 3), in agreement with other scheelite specimens (Rruff 2018). However, limited Raman spectroscopy data of scheelite is available. Raman bands 367 and $694 \mathrm{~cm}^{-1}$ were more intense for two of the scheelite grains. The spectroscopically examined HFO had bands at 88, 299, 383, 559, 684, 1000, and $1315 \mathrm{~cm}^{-1}$, in agreement with those of goethite (Kreissl et al. 2016).

\section{7-step sequential extraction}

Neither Fe nor W was released in concentrations above the detection limit in the first two steps of the 7-step sequential extraction, but both elements were released from easily reducible phases (step 3) through the whole profile of P4 (Fig. 4). The highest concentration of $\mathrm{W}$ released in step 3 was at $1.5 \mathrm{~m}$ (922 ppm), and the highest concentrations of Fe were at 0.3 and $1.5 \mathrm{~m}$. Tungsten was released in steps 4, 5, 6, and 7 in various amounts throughout the profile. Iron was released in step 4 (1.3 wt\% on average) and step 6 (2.5 wt \% on average) 


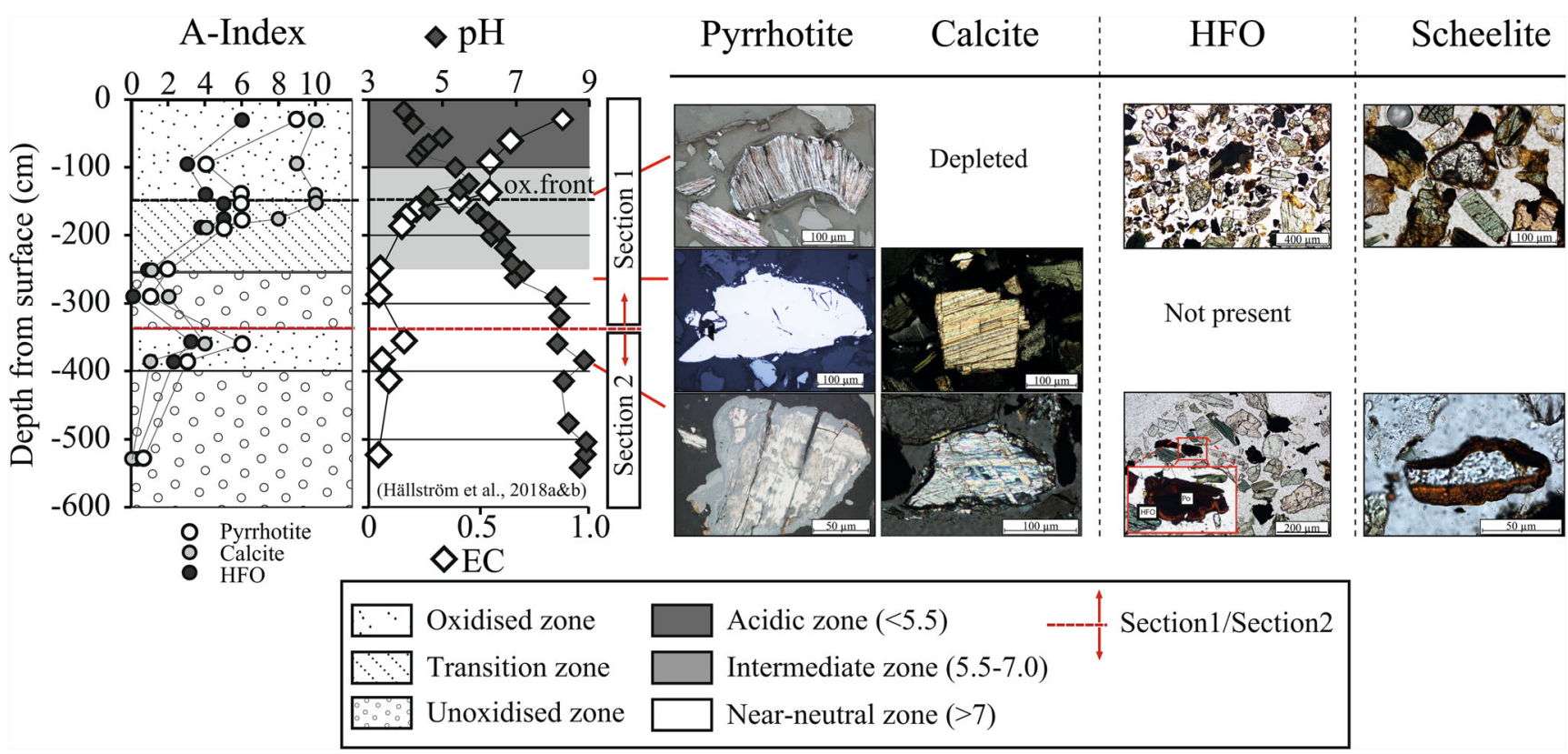

Fig. 2 Alteration indices (AI, for pyrrhotite, calcite, and HFO; see illustrative microscopic images, and text for methodological details); $\mathrm{pH}$ and $\mathrm{EC}$ measurements indicate two distinct sections in the $\mathrm{P} 4$ core.

originating from magnetite and sulfides. Approximately 60 $70 \%$ of the total Fe content in the tailings (8.0 wt\% on average) was in the residues and silicates obtained in step 7.

High amounts of $\mathrm{Ca}$ and $\mathrm{S}$ were released in step 1 from 0.3 and $1.5 \mathrm{~m}$ depth samples (Fig. 4), with an identical molar ratio to that of gypsum $\left(\mathrm{CaSO}_{4}\right)$. In step 2, up to $4 \mathrm{wt} \%$. of Ca was
Amorphous HFO around scheelite at $1.5 \mathrm{~m}$ depth and goethite around scheelite at $3.6 \mathrm{~m}$ depth are shown to the right

released from samples below $2.5 \mathrm{~m}$ depth, originating from calcite. Iron and $\mathrm{W}$ were both released from secondary oxyhydroxides (step 3) throughout the whole profile. The highest concentration of $\mathrm{W}$ released in step 3 was at $1.5 \mathrm{~m}$ (922 ppm), and the highest concentrations of Fe were at 0.3 and $1.5 \mathrm{~m}$. Aluminum and Mn were mainly found in extracts

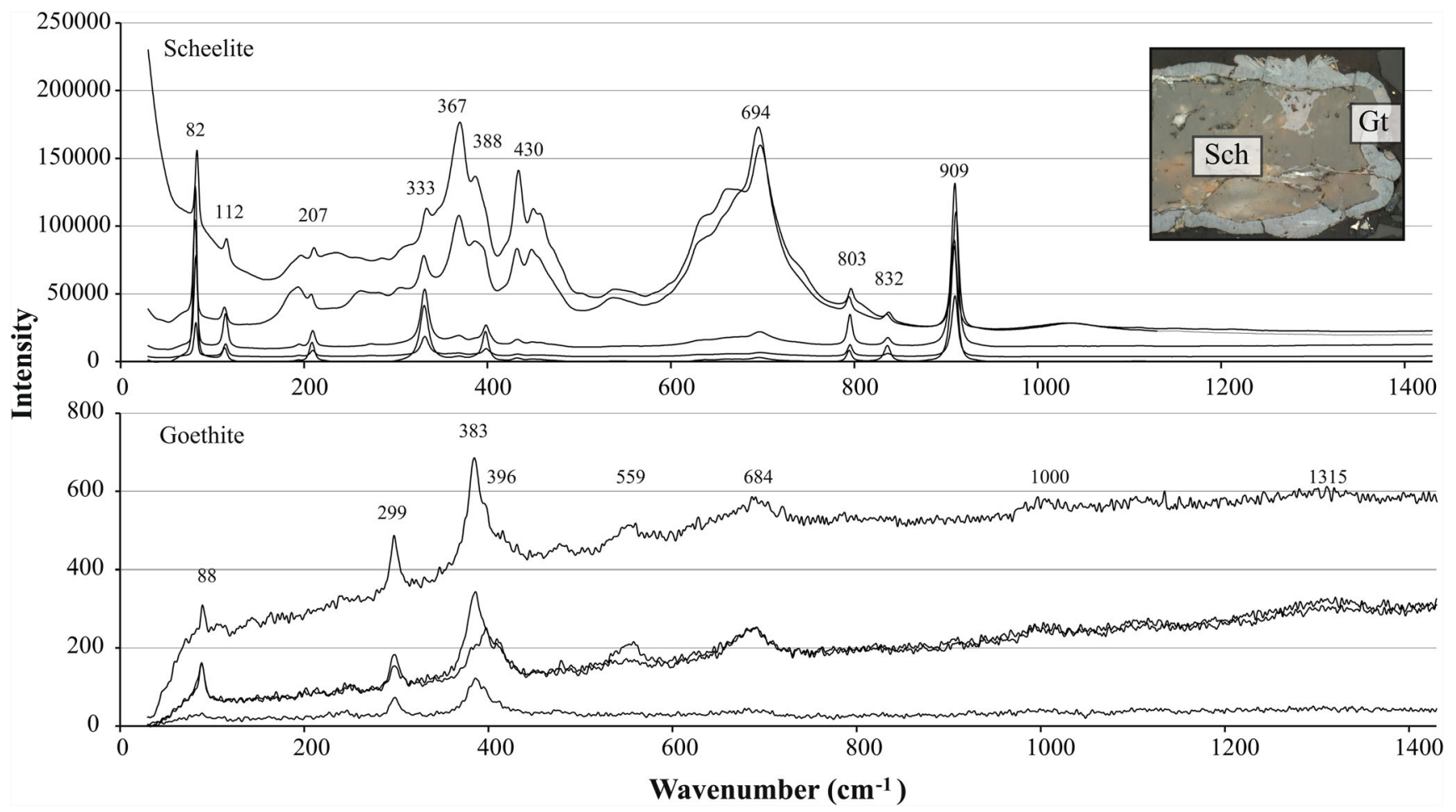

Fig. 3 Raman spectra of scheelite with rims of goethite from $3.6 \mathrm{~m}$ depth in the tailings 

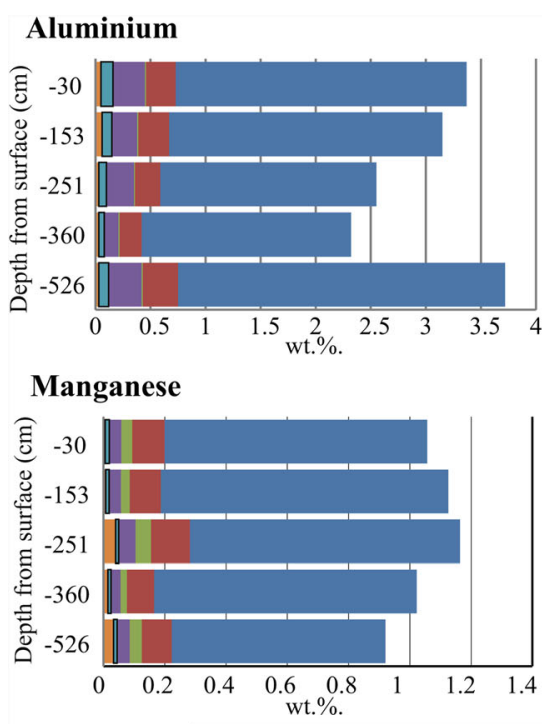
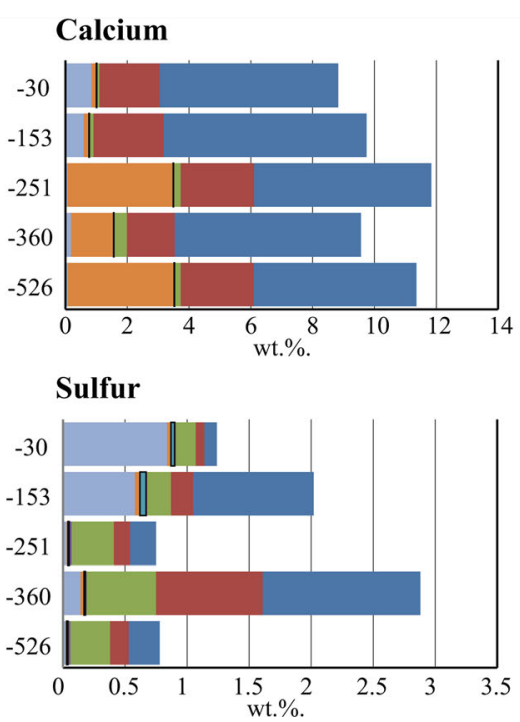
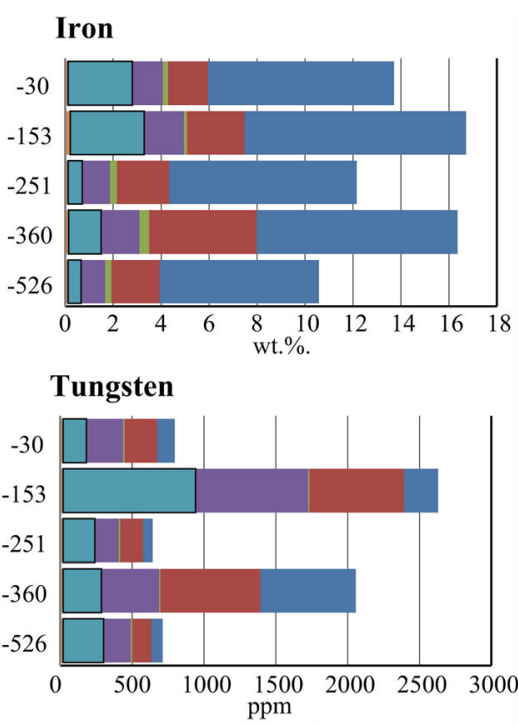

Step $6 \square$ Step 7
Fig. 4. Amounts of $\mathrm{Al}, \mathrm{Ca}, \mathrm{Fe}, \mathrm{Mn}, \mathrm{S}$, and $\mathrm{W}$ extracted from samples, at indicated depths, of the $\mathrm{P} 4$ core in the 7-step sequential extraction process, yielding (step 1) water-soluble phases, (step 2) exchangeable phases, (step 3) easily reducible minerals, (step 4) resistant reducible minerals, (step 5) easily oxidizable minerals, (step 6) resistant oxidizable minerals, and (step 7) residues and silicates obtained in steps 4, 6, and 7, indicating that they were in more stable minerals. Approximately 80, 60-70, 60-70, and 70$80 \%$ of the total $\mathrm{Al}, \mathrm{Ca}, \mathrm{Fe}$, and $\mathrm{Mn}$ contents in the tailings were in the residues and silicates obtained in step 7, in good agreement with amounts in silicates calculated by a modified element to mineral conversion (EMC) in a previous study by Hällström et al. (2018a).

\section{Element concentrations in groundwater and surface water}

The $\mathrm{pH}, \mathrm{EC}$, and $\mathrm{O}_{2}$ concentration of the groundwater at $\mathrm{P} 7$ was found to be $6.3 \pm 0.1$ and $2.6 \pm 0.06 \mathrm{mS} / \mathrm{cm}$ and $6.4 \mathrm{mg} / \mathrm{L}$, respectively, and its level varied between 0.7 and $1.3 \mathrm{~m}$ during the sampling occasions (Table 1). Dissolved concentrations of the major elements ( $\mathrm{Al}, \mathrm{Ca}, \mathrm{Fe}, \mathrm{K}, \mathrm{Mg}, \mathrm{Mn}, \mathrm{Na}, \mathrm{S}$, and $\mathrm{Si}$ ) were observed in the groundwater with small variations between the sampling occasions. Calcium and $\mathrm{S}$ were the dominant elements (average concentrations: 512 and $492 \mathrm{mg} / \mathrm{L}$, respectively). There was larger variation in the concentration of dissolved $\mathrm{W}(3 \mu \mathrm{g} / \mathrm{L}$ in May, and $\approx 22 \mu \mathrm{g} / \mathrm{L})$ from June to October.

In the surface water downstream of Smaltjärnen (at points $\mathrm{C} 7$ and $\mathrm{C} 11$ ), the average $\mathrm{pH}$ and EC were 5.8 and $300 \mu \mathrm{S} / \mathrm{cm}$, respectively, while the $\mathrm{pH}$ and $\mathrm{EC}$ of the reference, $\mathrm{C} 13, \mathrm{C} 14$, and C16 samples were $>6$ and $<40 \mu \mathrm{S} / \mathrm{cm}$, respectively. Dissolved concentrations of $\mathrm{Al}, \mathrm{Ca}, \mathrm{Fe}, \mathrm{K}, \mathrm{Mg}, \mathrm{Mn}, \mathrm{Na}, \mathrm{S}$, and $\mathrm{Si}$ in $\mathrm{C} 7$ and $\mathrm{C} 11$ samples were all high $(0.2,45,1.6,2.0$, $2.9,1.1,3.1,44,3.2 \mathrm{mg} / \mathrm{L}$ on average, respectively) compared with reference samples $(0.1,3.7,0.7,0.3,0.7,0.1,1.5,0.6$, and $1.9 \mathrm{mg} / \mathrm{L}$, respectively) (Table 1 ). The concentrations were lowest in May and increased gradually until September, coinciding with decreased waterflow. All the major elements, except $\mathrm{Fe}$, were mainly present in the dissolved phase (95\%, on average) on all sampling occasions in $\mathrm{C} 7$ and C11 samples. The percentage of Fe present in the dissolved phase varied between 16 and $73 \%$, with an average of $51 \%$. The concentrations of particulate Fe decreased between $\mathrm{C} 7$ and $\mathrm{C} 11$, with the $\mathrm{C} 7 / \mathrm{C} 11$-ratio: $1.5,1.9,2.0,10.3$, and 1.4 in May, June, July, August, September, and October, respectively.

Total detected $\mathrm{W}$ concentrations were higher in surface waters at all the sampling points than in the reference samples. Tungsten was present mainly in the particulate phase $(65 \%$ on average) at $\mathrm{C} 7$ and $\mathrm{C} 11$. The maximum total $\mathrm{W}$ concentration there was $1 \mu \mathrm{g} / \mathrm{L}, 98 \%$ of which was in the particulate phase. The concentrations of particulate $\mathrm{W}$ decreased between $\mathrm{C} 7$ and $\mathrm{C} 11$, with the $\mathrm{C} 7 / \mathrm{C} 11$-ratio: $1.5,1.7,3.3,1.9,1.8$, and 1.4 in May, June, July, August, September, and October, respectively. Dissolved W concentrations at C7 and C11 were not elevated compared with the reference samples $(<0.2$ $\mu \mathrm{g} / \mathrm{L})$. The highest detected concentrations of $\mathrm{W}$ in both dissolved and particulate phases were at C13 (1.7 and $1.3 \mu \mathrm{g} / \mathrm{L}$, respectively). The total concentrations of $\mathrm{W}$ at $\mathrm{C} 14$ and $\mathrm{C} 16$ were lower than at $\mathrm{C} 13$ but significantly higher than at $\mathrm{C} 11$. The concentrations of dissolved and particulate $\mathrm{W}$ in all reference samples were $<0.09 \mu \mathrm{g} / \mathrm{L}$, except for in one dissolved sample (August) and one particulate sample (July). The elevated concentrations could have been due to contamination of the sampling equipment, an analytical error, or naturally occurring $\mathrm{W}$ in the water. Measurements from these occasions are placed in brackets in Table 1 and omitted in Fig. 5. No 


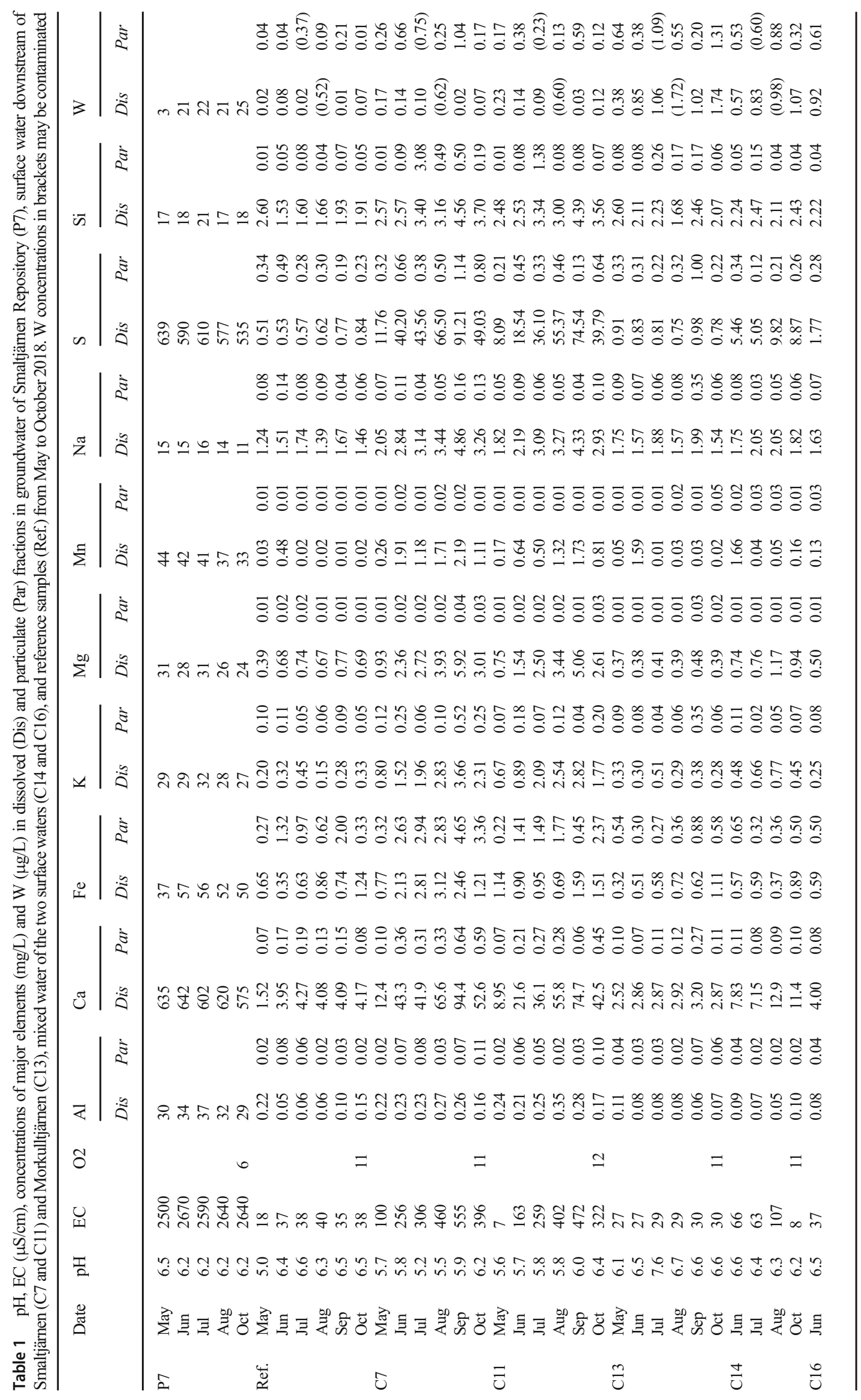


other element was found in abnormal concentrations in the reference sample, and the contamination is therefore assumed to only include W. No elevated concentrations of W were detected in blanks obtained after cleaning the filter equipment.

\section{Discussion}

Tungsten was primarily found in scheelite $\left(\mathrm{CaWO}_{4}\right)$ with an abundance of $0.1 \mathrm{wt} \%$ in the tailings at Yxsjöberg. Scheelite is considered to be a relatively stable mineral (Bokii and Anikin 1956), but little attention has been paid to its stability and the geochemical behavior of $\mathrm{W}$ in tailings. Scheelite grains with three characteristics were found in the tailings by optical microscopy: (1) unaltered grains, (2) grains with yellow rims at $1.5 \mathrm{~m}$ depth, and (3) grains with HFO rims at $3.6 \mathrm{~m}$ depth. Accordingly, variations in $\mathrm{W}$ concentration with depth have been previously detected at P4 and P7, including clear peaks at 1.5 and $3.6 \mathrm{~m}$ depths at P4 (Hällström et al. 2018a) (Fig. 5).

\section{Section 1: W mobility in the later deposition period}

Detailed analysis of the P4 core using the 7-step sequential extraction procedure showed that $30 \%$ of $\mathrm{W}(922 \mathrm{mg} / \mathrm{kg})$ in the peak at $1.5 \mathrm{~m}$ was associated with easily reducible phases (Fig. 5). However, the extraction procedure was not developed for scheelite and some uncertainties and analytical problems were encountered. For example, it was not clear in which step scheelite dissolved and amounts of $\mathrm{W}$ extracted in the seven steps are substantially smaller than total amounts detected in the tailings. Old scheelite concentrate from the processing plant was analyzed by the sequential extraction in attempt to clarify in which step scheelite was dissolved, without success. With that in mind, the 7-step sequential extraction results indicated that weathering of scheelite and secondary capturing of $\mathrm{W}$ in easily reducible phases had occurred in the upper-parts of the tailings where $\mathrm{pH}$ was $>7$. Concentrations of $\mathrm{W}$ in the watersoluble (Hällström et al. 2018b) and exchangeable phases were below the detection limit, indicating that $\mathrm{W}$ was strongly bound to the easily reducible phases. Indications of scheelite alteration were observed by optical microscopy as formations of a yellow rim inter-grown on scheelite surfaces, as reportedly formed through incongruent weathering of scheelite with precipitates of insoluble tungstic acid $\left(\mathrm{H}_{2} \mathrm{WO}_{4}\right)$ (Marinakis and Kelsall 1987; Montgomery and McKibben 2012). According to Montogmery and McKibben (Montgomery and McKibben 2012), tungstic acid forms during scheelite dissolution at $\mathrm{pH}$ 3 or lower; above this $\mathrm{pH}$, the rate of scheelite dissolution increases with $\mathrm{pH}$ and temperature.

Iron was the dominating oxyhydroxide at this depth and adsorption/co-precipitation with HFO has been proven to immobilize $\mathrm{W}$ at $\mathrm{pH}$ conditions below 8 (Gustafsson 2003). This

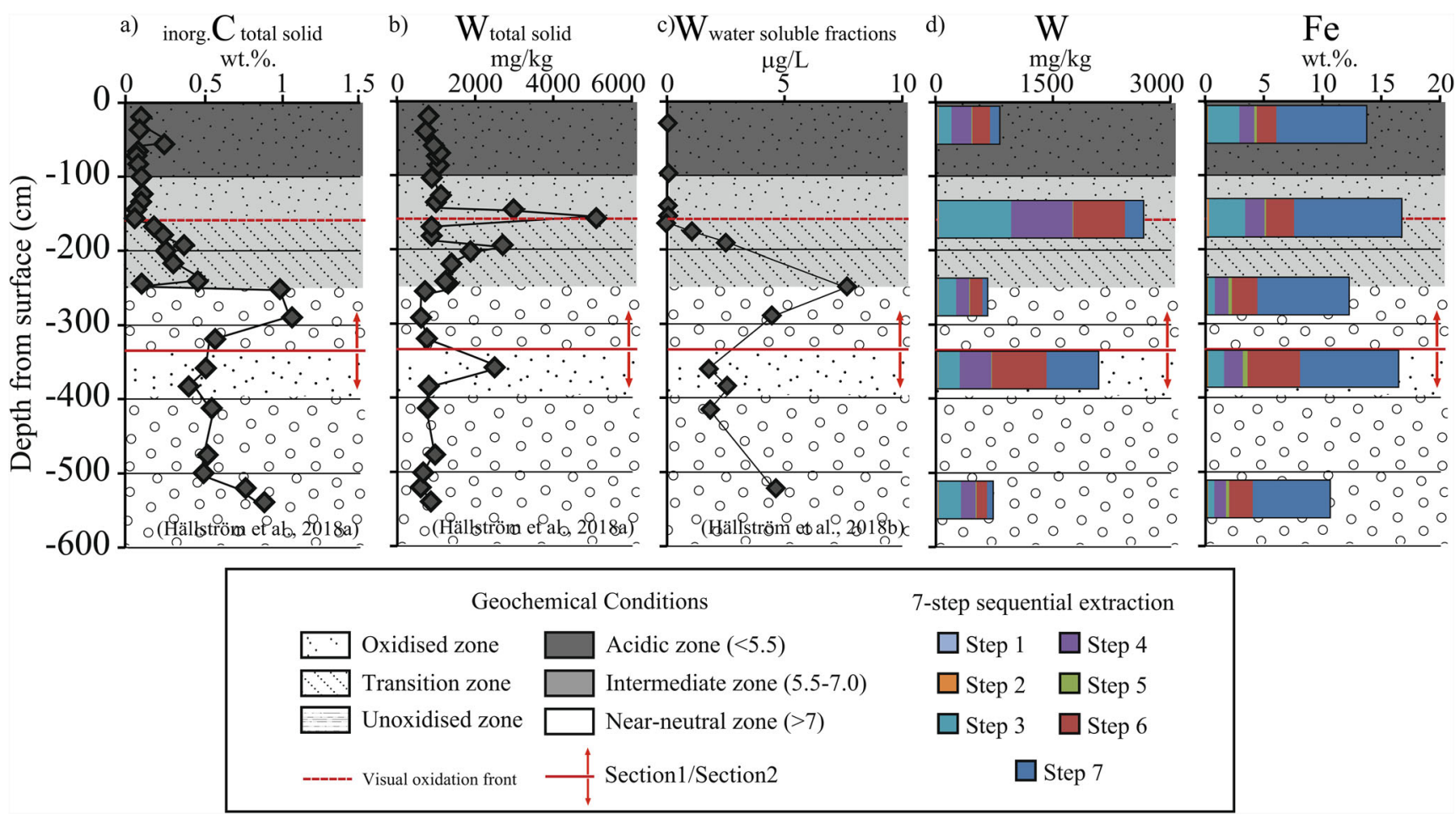

Fig. 5 Results of analysis of the P4 core. (a) Total inorganic C content (wt\%), (b) total W content ( $\mathrm{mg} / \mathrm{kg}$ ), (c) W concentration in water-soluble phases, and (d) W and Fe contents in fractions obtained from the 7-step sequential extraction: (1) water-soluble phases, (2) exchangeable phases,
(3) easily reducible minerals, (4) resistant reducible minerals, (5) easily oxidizable minerals, (6) resistant oxidizable minerals, and (7) residues and silicates 
can occur by either $\mathrm{W}$ substituting $\mathrm{Fe}^{3+}$ in the crystal lattice of ferrihydrite (Kreissl et al. 2016) or formation of strong innersphere complexes (Kashiwabara et al. 2013). In the upper tailings (at depths $<1.5 \mathrm{~m}$ ), amorphous HFO was present around all examined mineral grains, it had replaced pyrrhotite completely, and formed thicker rims around chalcopyrite and pyrite. Iron originated mainly from oxidation of pyrrhotite (Eqs. 1 and 2) (Hällström et al. 2018a).

$$
\begin{aligned}
& \mathrm{Fe}_{(1-x)} \mathrm{S}+\left(2-\frac{x}{2}\right) \mathrm{O}_{2}+x \mathrm{H}_{2} \mathrm{O} \leftrightarrow(1-x) \mathrm{Fe}^{2+}+\mathrm{SO}_{4}^{2-} \\
& \quad+2 x \mathrm{H}^{+}(x=0.08) \\
& \mathrm{Fe}^{2+}+\frac{1}{4} \mathrm{O}_{2}+\frac{5}{2} \mathrm{H}_{2} \mathrm{O} \leftrightarrow \mathrm{Fe}(\mathrm{OH})_{3(s)}+2 H^{+}
\end{aligned}
$$

It was not possible to distinguish the type of HFO present in the oxidized acidic tailings due to the amorphous structure, but from the literature, 2-line ferrihydrite is known to be the first phase formed during early stages of $\mathrm{Fe}^{2+}$ oxidation at low temperatures under near-surface conditions with $\mathrm{pH}>4$ (Kreissl et al. 2016). Except for $\mathrm{HFO}, \mathrm{Al}$ and $\mathrm{Mn}$ oxyhydroxides have also been seen to scavenge W (Bauer et al. 2017a; Hur and Reeder 2016). However, $\mathrm{Al}$ and $\mathrm{Mn}$ contents of fractions obtained in step 3 in the extraction of samples from Yxsjöberg were much lower than the Fe contents, so the adsorption/co-precipitation of $\mathrm{W}$ to their oxyhydroxides is assumed to be insignificant.

At present time, the release of $\mathrm{W}$ was ongoing at $2.5 \mathrm{~m}$ depth in unoxidized tailings with near-neutral $\mathrm{pH}$ (Fig. 5), and associated reactions putatively involved (across the profile in the tailings) are illustrated in Fig. 6. At $2.5 \mathrm{~m}$ depth, elevated concentrations of $\mathrm{W}$ were released in water-soluble phases correlated with lower content of $\mathrm{W}$ in the tailings. At the same depth, the $\mathrm{pH}$ is above 7 and $\mathrm{C}$ has precipitated mainly as secondary orthogonal calcite (Hällström et al. 2018a). Water-soluble phases of W coinciding with accumulation of $\mathrm{C}$ have also been found in another core from Yxsjöberg (Salifu et al. 2018). Siderite $\left(\mathrm{FeCO}_{3}\right)$ is commonly reported in secondary carbonates in tailings from sulfidic deposits (Blowes et al. 2003), but was not found in the thin section from $2.5 \mathrm{~m}$ depth. The high abundance of $\mathrm{Ca}$ released from fluorite and calcite weathering could favor formation of secondary Ca-carbonates rather than $\mathrm{Fe}$-carbonates. The formation of secondary carbonates is supported by enriched $\mathrm{C}$-isotope ratios at similar depths in the additional core from the Yxsjöberg tailings (Salifu et al., unpublished data). The accumulated $\mathrm{C}$ was originally released in the upper acidic oxidized and transition zones due to calcite neutralizing acid produced from pyrrhotite oxidation (Eq.3) and transported downwards to conditions where $\mathrm{pH}>7$.

$\mathrm{CaCO}_{3}+\mathrm{H}^{+} \leftrightarrow \mathrm{Ca}^{2+}+\mathrm{HCO}_{3}^{-}$

It is hypothesized that small proportions of $\mathrm{CO}_{3}{ }^{2-}$ have displaced $\mathrm{WO}_{4}{ }^{2-}$ at the surfaces of scheelite at this depth, instead of precipitating as calcite, thereby releasing $\mathrm{W}$ to the pore water according to Eq. 4, and as illustrated in Fig. 4.

$\mathrm{CaWO}_{4(s)}+\mathrm{HCO}_{3(a q)}^{-} \leftrightarrow \mathrm{CaCO}_{3(s)}+\mathrm{WO}_{4}^{2-}+\mathrm{H}^{+}$

This has not been mineralogically confirmed, due to the lack of scheelite in the thin section from this depth, but is in good agreement with results presented by Atademir et al. (1979), Marinakis and Kelsall (1987), and Montgomery and McKibben (2012). At Yxsjöberg, elevated concentrations of dissolved $\mathrm{W}$ were found in the groundwater of the tailings (up to $22 \mu \mathrm{g} / \mathrm{L}$ ) and elevated concentrations of total $\mathrm{W}$ in the surface water downstream of the repository (up to $1 \mu \mathrm{g} / \mathrm{L}$ ) compared with the reference water $(<0.2 \mu \mathrm{g} / \mathrm{L})$. These findings confirm that $\mathrm{W}$ is released from scheelite in the tailings and transported out of the impoundment. Weathering of scheelite in the tailings is assumed to be an indirect effect of the pyrrhotite oxidation. Hence, skarn tailings without sulfide oxidation or without contact with atmosphere or limited amount of calcite might produce mine water drainage with limited concentrations of $\mathrm{W}$.

\section{Section 2: W mobility in the older deposition period}

A similar sequence to the one inferred in section 1 with pyrrhotite oxidation $\rightarrow$ calcite alteration $\rightarrow$ downward transport of $\mathrm{CO}_{3}{ }^{2-}, \rightarrow$ accumulation of $\mathrm{C} \rightarrow$ decrease solid $\mathrm{W}$ and increase water-soluble phases of $\mathrm{W}$ occurred in section 2 (Fig. 4). Compared with section 1, the HFO formed in the older oxidized zone in section 2 with near-neutral $\mathrm{pH}$ were crystalline goethite, and were only present around pyrrhotite, magnetite, and scheelite (Figs. 2 and 6). The occurrence of goethite as rims on scheelite has been studied in the laboratory by Gao et al. (2016) and is due to negatively charged surfaces of scheelite attracting $\mathrm{Fe}^{3+}$. Low concentrations of $\mathrm{W}$ are released into the water-soluble phase at this depth (Hällström et al. 2018b). The rims could inhibit scheelite weathering by limiting the possibility of $\mathrm{CO}_{3}{ }^{2-}$ released from upper layers interacting with the scheelite surfaces. Released $\mathrm{WO}_{4}{ }^{2-}$ could also be scavenged in the tailings by adsorption or coprecipitation processes (Kreissl et al. 2016), which would reduce concentrations of $\mathrm{W}$ in the water-soluble phases and reaching the groundwater. Tungstate currently released from the tailings lying above in section 1 would adsorb to the already existing goethite, and $\mathrm{WO}_{4}{ }^{2-}$ released during primary formation of HFO could be co-precipitated in the crystal lattice of goethite (Kreissl et al. 2016).

\section{W mobility in groundwater and surface water}

The long-term storage of tailings in ambient conditions with apparent pyrrhotite oxidation, calcite depletion, silicate, and dissolution of secondary gypsum has affected the water quality 


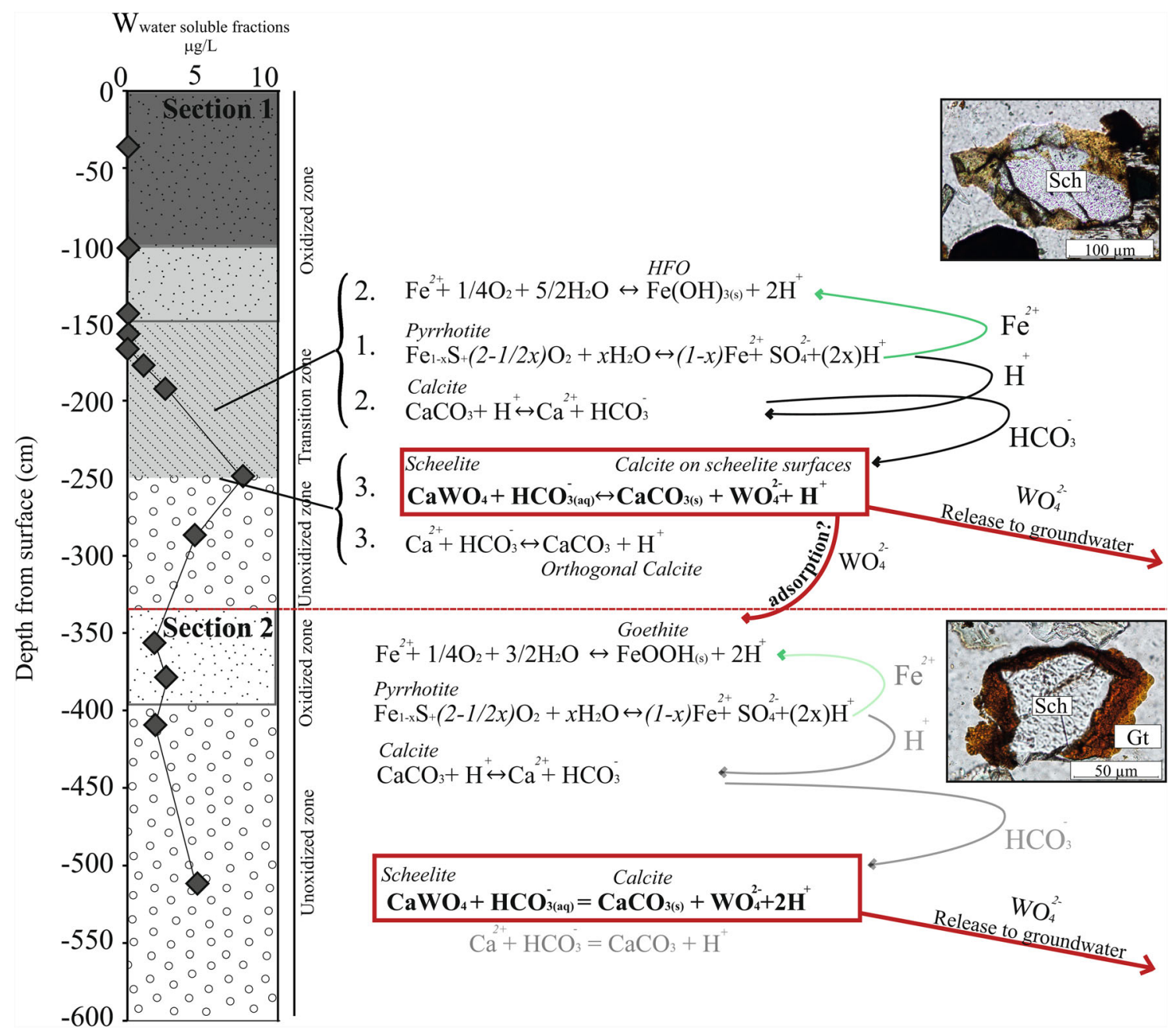

Fig. 6 The hypothesized sequence of (1) pyrrhotite oxidation $\rightarrow$ (2) calcite depletion $\rightarrow$ release of $\mathrm{HCO}_{3}{ }^{2-}$ and transport downwards $\rightarrow$ (3) anion exchange between $\mathrm{HCO}_{3}{ }^{2-}$ and $\mathrm{WO}_{4}{ }^{2-} \rightarrow \mathrm{WO}_{4}{ }^{2-}$ release to groundwater

downstream of the Smaltjärnen Repository. A higher rate of pyrrhotite oxidation than calcite neutralization in the tailings has resulted in release of acid to the surface water, generating low $\mathrm{pH}$ at $\mathrm{C} 7$ and $\mathrm{C} 11$ (Fig. 7), although neutralization calculations showed that calcite should have the potential to neutralize the acidity produced (Hällström et al. 2018a). The higher rate of pyrrhotite weathering compared with calcite shows the necessity of other prediction tools than only static tests. The $\mathrm{EC}$ was $\approx 345$ $\mu \mathrm{S} / \mathrm{cm}$ downstream Smaltjärnen Lake (C7), indicating a high release of ions into the water. Calcium and $\mathrm{S}$ were the dominating elements in the surface water, with concentrations up to 94 and $91 \mathrm{mg} / \mathrm{L}\left(273 \mathrm{mg} / \mathrm{L} \mathrm{SO}_{4}{ }^{2-}\right)$, respectively, and they were nearly entirely present in the dissolved phase (> 99\%) downstream of the repository (C7 and C11). The concentrations were lower during the spring flood in May and increased gradually with reductions in water flow until September (Fig. 7). The molar $\mathrm{Ca}$ to $\mathrm{S}$ ratio was close to that of gypsum (1:1.2-1.3, molar ratio of $\mathrm{Ca}: \mathrm{SO}_{4}$ ), showing that some of the secondary gypsum formed in the upper oxidized acidic tailings has been dissolved or adsorption to goethite, illustrated with depth in sections 1 and 2 . Microscopic images of altered scheelite at $1.5 \mathrm{~m}$ and scheelite with goethite rim at $2.6 \mathrm{~m}$ are shown in the pictures

and transported from the repository. The concentrations of released $\mathrm{Ca}$ and $\mathrm{SO}_{4}{ }^{2-}$ are relatively low compared with those detected in other $\mathrm{W}$ mining areas (Candeias et al. 2015) and the $\mathrm{SO}_{4}{ }^{2-}$ concentration was below the threshold value for taste in drinking water (370 mg/L) (World Health Organization 2004).

Iron was present in both dissolved and particulate phases in the surface water downstream of Smaltjärnen, and the highest concentrations were detected at $\mathrm{C} 7$ on all sampling occasions. There, Fe was the main particulate element, accounting for $53 \%$, on average, of all elements in fractions $>0.2 \mu \mathrm{m}$. Total concentrations of Fe released from the tailings were significantly lower than the $\mathrm{S}$ concentrations, indicating that a large proportion of $\mathrm{Fe}$ released from pyrrhotite oxidation had been captured as HFO in the tailings. This is consistent with results of the 7-step sequential extraction. The Fe concentrations at $\mathrm{C} 11$ were similar to those in the reference samples, suggesting that large proportions of $\mathrm{Fe}$ precipitated in the sediments between $\mathrm{C} 7$ and $\mathrm{C} 11$. The Fe concentrations at $\mathrm{C} 13$, $\mathrm{C} 14$, and $\mathrm{C} 16$ were similar to the reference values (Fig. 7). 


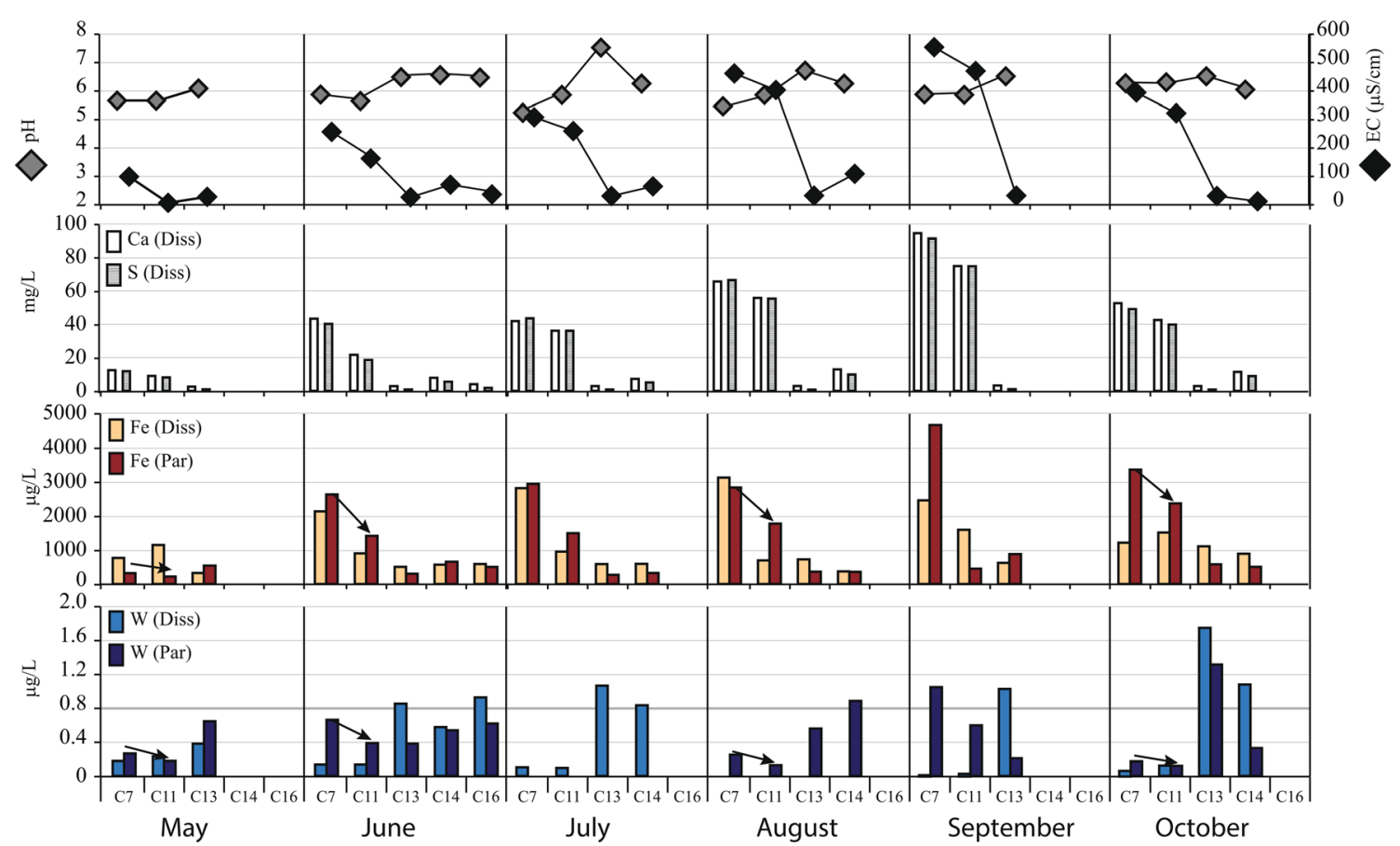

Fig. 7 Monthly pH, EC, dissolved (Diss) Ca and S, dissolved and particulate (Par) Fe, and dissolved and particulate W at C7, C11, C13, C14, and C16. The arrows indicate times when the sedimentation ratio of Fe between $\mathrm{C} 7$ and $\mathrm{C} 11$ was similar to that of $\mathrm{W}$

The concentrations of $\mathrm{W}$ in the groundwater from Smaltjärnen Repository and downstream surface waters were low on all sampling occasions, but still higher than in the reference sample. Tungsten was mainly present in the particulate fraction at sampling points $\mathrm{C} 7$ and $\mathrm{C} 11$, coinciding with the high concentrations of particulate Fe. Particulate $\mathrm{W}$ is known to have high affinity for particulate $\mathrm{Fe}$ in natural rivers (Bauer et al. 2017b) and a correlation between the sedimentation of $\mathrm{Fe}$ and $\mathrm{W}$ between $\mathrm{C} 7$ to $\mathrm{C} 11$ was found. Thus, it is hypothesized that tungsten was released as $\mathrm{WO}_{4}{ }^{2-}$ from the groundwater in the Smaltjärnen tailings and adsorbed to particulate Fe precipitated in the surface water. The concentrations of $\mathrm{W}$ and $\mathrm{Fe}$ in groundwater (at P7) were approximately 30 times higher than those at C7 during May, and decreased similarly with decreasing water flow in the surface water. The difference may be due to either (co-)precipitation of secondary minerals or dilution by the water in Smaltjärnen Lake. However, the differences in concentrations were of the same order of magnitude as the drop in $\mathrm{Mg}$ concentration (10- to 30fold) between P7 and C7. Magnesium is a good dilution indicator because it does not readily enter secondary minerals or biota. Thus, these findings suggest that most $\mathrm{Fe}$ and $\mathrm{W}$ leaving the repository with the mine drainage are transported away from the repository by the surface water. Particulate $\mathrm{W}$ is hypothesized to subsequently settle between $\mathrm{C} 7$ and $\mathrm{C} 11$, with particulate $\mathrm{Fe}$, thus, the ratio between $\mathrm{W}$ in $\mathrm{C} 7$ and $\mathrm{C} 11$ and $\mathrm{Fe}$ was similar in May, June, August, and October.

No environmental regulations or general guideline values for dissolved $\mathrm{W}$ in surface waters have been set in the EU or
USA, due to the lack of knowledge of its mobility and toxicity (Koutsospyros et al. 2006; Strigul 2010). In Russia, a maximum allowed concentration of $0.8 \mu \mathrm{g} / \mathrm{L}$ dissolved $\mathrm{W}$ has been set for aquatic systems used for fishing (Strigul et al. 2009). The concentrations of $\mathrm{W}$ in the dissolved phase downstream of Smaltjärnen were all below this threshold, and thus too low for it to be considered hazardous according to this guideline. However, dissolved concentrations of $\mathrm{W}$ above $0.8 \mu \mathrm{g} / \mathrm{L}$ were detected in surface water downstream of Morkulltjärnen Repository (at C13) during June to October. The $\mathrm{pH}$ at $\mathrm{C} 13$ varied between 6.0 and 7.6, and low concentrations of particulate Fe were present. Thus, monometric tungstate was probably the dominating species (Koutsospyros et al. 2006). The W concentrations in mixed water between Smaltjärnen and Morkulltjärnen at $\mathrm{C} 14$ and $\mathrm{C} 16$ were highly affected by the high concentrations of $\mathrm{W}$ from $\mathrm{C} 13$ and concentrations above $0.8 \mu \mathrm{g} / \mathrm{L}$ were measured during June, July, August, September, and October. The $\mathrm{W}$ concentrations at $\mathrm{C} 13, \mathrm{C} 14$, and $\mathrm{C} 16$ were still low compared with concentrations reported downstream of other W mining areas by Candeias et al. (2015), Gurbanov et al. (2015), and Seiler et al. (2005), but higher than concentrations detected in rivers downstream of industrial areas, e.g., in Japan (Koutsospyros et al. 2006). This indicates that the $\mathrm{W}$ contamination previously detected by the municipality originates from Morkulltjärnen Repository. Further investigations, including geochemical characterization of Morkulltjärnen Repository, are needed to understand the release of $\mathrm{W}$ from this source. 


\section{Conclusion}

- Partial dissolution of scheelite releases some $\mathrm{W}$ to mine drainage. The weathering process is hypothesized to be due to anion exchange with $\mathrm{CO}_{3}{ }^{2-}$ on the surfaces of scheelite in unoxidized conditions where $\mathrm{pH}$ is above 7. The $\mathrm{CO}_{3}{ }^{2-}$ was released during calcite neutralization of acidity produced from pyrrhotite oxidation and thereafter transported downwards in the tailings.

- Some of the $\mathrm{W}$ that is released from scheelite can adsorb to HFO and remain immobilized within the tailings. Some of the $\mathrm{W}$ that is transported away from the tailings appears to co-precipitate downstream with HFO.

- Elevated concentrations of W were found in the groundwater of the tailings and in surface water downstream the tailings confirming weathering of scheelite. However, the concentrations were not large enough to be classified as a contaminant according to today's water regulations.

- Released W from scheelite was co-precipitated with amorphous HFO in oxidized acidic tailings, and possibly adsorbed to goethite in an old oxidized layer in the deep tailings.

Acknowledgments Open access funding provided by Luleå University of Technology. We thank our colleagues involved in the collaborative REMinE project, from Luleå University of Technology (LTU) in Sweden, Porto University in Portugal, and the National Institute for Metals and Radioactive Resources in Romania. Special thanks are due to Musah Salifu for all the fieldwork we have done together, and Dr Thomas Aiglsperger for help with Raman measurements.

Funding information This work was supported by Vinnova [grant no. 21506 631] and co-funded by the Center of Advanced Mining and Metallurgy $\left(\mathrm{CAMM}^{2}\right)$ at LTU.

Open Access This article is licensed under a Creative Commons Attribution 4.0 International License, which permits use, sharing, adaptation, distribution and reproduction in any medium or format, as long as you give appropriate credit to the original author(s) and the source, provide a link to the Creative Commons licence, and indicate if changes were made. The images or other third party material in this article are included in the article's Creative Commons licence, unless indicated otherwise in a credit line to the material. If material is not included in the article's Creative Commons licence and your intended use is not permitted by statutory regulation or exceeds the permitted use, you will need to obtain permission directly from the copyright holder. To view a copy of this licence, visit http://creativecommons.org/licenses/by/4.0/.

\section{References}

Atademir MR, Kitchener JA, Shergold HL (1979) The surface chemistry and flotation of scheelite. I. Solubility and surface characteristics of precipitated calcium tungstate. J Colloid Interface Sci 71:466-476. https://doi.org/10.1016/0021-9797(79)90321-7.

Bauer S, Blomqvist S, Ingri J (2017a) Distribution of dissolved and suspended particulate molybdenum, vanadium, and tungsten in the Baltic Sea. Mar Chem 196:135-147
Bauer, S., Conrad, S., Ingri, J., 2017b. Seasonal behavior of molybdenum, vanadium, and tungsten in boreal rivers. In Doctoral Thesis: Dissolved and suspended transport of tungsten, molybdenum, and vanadium in natural waters. ISBN: 978-91-7790-014-6. Luleå University of Technology.

Bednar AJ, Jones WT, Chappell MA, Johnson DR, Ringelberg DB (2010) A modified acid digestion procedure for extraction of tungsten from soil. Talanta 80:1257-1263

Blowes DW, Jambor JL (1990) The pore-water geochemistry and the mineralogy of the vadose zone of sulfide tailings, Waite Amulet, Quebec, Canada. Appl Geochem 5:327-346

Blowes DW, Ptacek CJ, Jambor JL, Weisener CG (2003) The geochemistry of acid mine drainage. Treatise on Geochemistry 9(612):150 195

Bokii GB, Anikin IN (1956) Determination of the solubility of scheelite in water and aqueous solutions. Zhurnal Neorganicheskoi Khimii 1: 1926-1928

Candeias C, Ávila PF, Da Silva EF, Ferreira A, Durães N, Teixeira JP (2015) Water-rock interaction and geochemical processes in surface waters influenced by tailings impoundments: impact and threats to the ecosystems and human health in rural communities (Panasqueira mine, central Portugal). Water Air Soil Pollut 226:1-30

Cui M, Johannesson KH (2017) Comparison of tungstate and tetrathiotungstate adsorption onto pyrite. Chem Geol 464:57-68

Datta S, Vero SE, Hettiarachchi GM, Johannesson K (2017) Tungsten contamination of soils and sediments: current state of science. Curr Pollut Rep: $1-10$

Dold B (2003) Speciation of the most soluble phases in a sequential extraction procedure adapted for geochemical studies of copper sulfide mine waste. J Geochem Explor 80:55-68

Gao Z, Hu Y, Sun W, Drelich JW (2016) Surface-charge anisotropy of scheelite crystals. Langmuir 32:6282-6288

Gurbanov AG, Bogatikov OA, Vinokurov SF, Karamurzov BS, Gazeev VM, Leksin AB, Shevchenko AV, Dolov SM, Dudarov ZI (2015) Geochemical evaluation of environmental conditions in the area of activity of the Tyrnyauz tungsten-molybdenum plant (KabardinoBalkaria, North Caucasus): Sources of environment contamination, impact upon neighboring areas, and ways for recovery. Dokl Earth Sci 464:967-971

Gustafsson JP (2003) Modelling molybdate and tungstate adsorption to ferrihydrite. Chem Geol 200:105-115

Hällström LP, Alakangas L, Martinsson O (2018a) Geochemical characterization of $\mathrm{W}, \mathrm{Cu}$ and $\mathrm{F}$ skarn tailings at Yxsjöberg, Sweden. J Geochem Explor

Hällström, L.P., Alakangas, L., Martinsson, O., 2018b. Metal release from acidic and near-neutral $\mathrm{pH}$-conditions in historical $\mathrm{W}, \mathrm{Cu}$ and F skarn tailings at Yxsjöberg, Sweden. 11th ICARD, IMWA, MWD Conference - "Risk to Opportunity".

Höglund, L.O., Jones, C., Lindgren, M., 2004. Förstudie för efterbehandling av sandmagasin i Yxsjöberg. Kemakta AR 200323.

Höglund, L.O., Jones, C., Lindgren, M., 2005. Kompletterande studie av sandmagasinen i Yxsjöberg, gällande belastning på recipienter av beryllium och volfram inklusive uppdaterad MIFO-2 klassning. Kemakta AR 2005-25.

Hur H, Reeder RJ (2016) Tungstate sorption mechanisms on boehmite: systematic uptake studies and X-ray absorption spectroscopy analysis. J Colloid Interface Sci 461:249-260

Johannesson KH, Dave HB, Mohajerin TJ, Datta S (2013) Controls on tungsten concentrations in groundwater flow systems: the role of adsorption, aquifer sediment Fe(III) oxide/oxyhydroxide content, and thiotungstate formation. Chem Geol 351:76-94

Kashiwabara T, Takahashi Y, Marcus MA, Uruga T, Tanida H, Terada Y, Usui A (2013) Tungsten species in natural ferromanganese oxides related to its different behavior from molybdenum in oxic ocean. Geochim Cosmochim Acta 106:364-378 
Kennedy AJ, Johnson DR, Seiter JM, Lindsay JH, Boyd RE, Bednar AJ, Allison PG (2012) Tungsten toxicity, bioaccumulation, and compartmentalization into organisms representing two trophic levels. Environ Sci Technol 46:9646-9652

Koutsospyros A, Braida W, Christodoulatos C, Dermatas D, Strigul N (2006) A review of tungsten: from environmental obscurity to scrutiny. J Hazard Mater 136:1-19

Kreissl S, Bolanz R, Göttlicher J, Steininger R, Tarassov M, Markl G (2016) Structural incorporation of W6 into hematite and goethite: a combined study of natural and synthetic iron oxides developed from precursor ferrihydrite and the preservation of ancient fluid compositions in hematite. Am Mineral 101:2701-2715

Kwak, T.A., 2012. W-Sn skarn deposits: and related metamorphic skarns and granitoids. Elsevier.

Lemus R, Venezia CF (2015) An update to the toxicological profile for water-soluble and sparingly soluble tungsten substances. Crit Rev Toxicol 45:388-411

Lin C, Li R, Cheng H, Wang J, Shao X (2014) Tungsten distribution in soil and rice in the vicinity of the world's largest and longestoperating tungsten mine in China. PLoS One 9:e91981

Lindsay JH, Kennedy AJ, Seiter-Moser JM, Bednar AJ, Boyd RE, Johnson DR, Allison P, Tappero RV (2017) Uptake kinetics and trophic transfer of tungsten from cabbage to a herbivorous animal model. Environ Sci Technol 51:13755-13762

Marinakis KI, Kelsall GH (1987) The surface chemical properties of scheelite (CaWO4) I. The scheelite/water interface and $\mathrm{CaWO}_{4}$ solubility. Colloids Surf A Physicochem Eng Asp 25:369-385. https:// doi.org/10.1016/0166-6622(87)80315-3

Meinert LD (1992) Skarns and skarn deposits. Geosci Can 19

Mohajerin TJ, Helz GR, White CD, Johannesson KH (2014) Tungsten speciation in sulfidic waters: determination of thiotungstate formation constants and modeling their distribution in natural waters. Geochim Cosmochim Acta 144:157-172

Moncur MC, Jambor JL, Ptacek CJ, Blowes DW (2009) Mine drainage from the weathering of sulfide minerals and magnetite. Appl Geochem 24:2362-2373

Montgomery, S.D., McKibben, M.A., 2012. Kinetics of the dissolution of scheelite in groundwater: implications for environmental and economic geology. USGS MRERP Grant G09AC00037.

Odman F, Ruth T, Pontér C (1999) Validation of a field filtration technique for characterization of suspended particulate matter from freshwater. Part I. Major elements 1. Appl Geochem 14:301-317

Petta RA, Sindern S, Souza RF, Campos TF (2014) Influence of mining activity on the downstream sediments of scheelite mines in Currais Novos (NE Brazil). Environ Earth Sci 72:1843-1852
Ray GE, Webster I, Ettlinger AD (1995) The distribution of skarns in British Columbia and the chemistry and ages of their related plutonic rocks. Econ Geol 90:920-937

Rothelius, E., 1957. Swedish mineral dressing mills, short descriptions and flowsheets. International Mineral Dressing Congress Stockholm, 1-9.

Rruff. http://ruff.info/scheelite/display=default/. Date: 2018-10-10.

Salifu M, Aiglsperger T, Hällström L, Martinsson O, Billström K, Ingri J, Dold B, Alakangas L (2018) Strontium ( $87 \mathrm{Sr} / 86 \mathrm{Sr}$ ) isotopes: a tracer for geochemical processes in mineralogically-complex mine wastes. Appl Geochem 99:42-54

Seiler RL, Stollenwerk KG, Garbarino JR (2005) Factors controlling tungsten concentrations in ground water, Carson Desert. Nevada Appl Geochem 20:423-441

Strigul N (2010) Does speciation matter for tungsten ecotoxicology? Ecotoxicol Environ Saf 73:1099-1113

Strigul N, Koutsospyros A, Arienti P, Christodoulatos C, Dermatas D, Braida W (2005) Effects of tungsten on environmental systems. Chemosphere 61:248-258

Strigul N, Koutsospyros A, Christodoulatos C (2009) Tungsten in the former Soviet Union: review of environmental regulations and related research. Land Contamination and Reclamation 17:189

Strigul N, Koutsospyros A, Christodoulatos C (2010) Tungsten speciation and toxicity: acute toxicity of mono-and poly-tungstates to fish. Ecotoxicol Environ Saf 73:164-171

U.S Environmental Protection Agency, 2014. Technical fact sheet - tungsten, EPA 505-F-14-004.

Werner, A.B., Sinclair, W.D., Amey, E.B., 1998. International Strategic Mineral Issues Summary Report - tungsten. U.S. Geological Survey Circular 930-O.

Wilson B, Pyatt FB (2006) Bio-availability of tungsten in the vicinity of an abandoned mine in the English Lake District and some potential health implications. Sci Total Environ 370:401-408

Wilson B, Pyatt FB (2009) Persistence and bioaccumulation of tungsten and associated heavy metals under different climatic conditions. Land Contam Reclam 17:93-100

World Health Organization, 2004. Sulfate in drinking-water, background document for development of WHO guidelines for drinking-water quality. WHO/SDE/03.04/114.

Zoroddu MA, Medici S, Peana M, Nurchi VM, Lachowicz JI, LaulichtGlickc F, Costa M (2018) Tungsten or wolfram: friend or foe? Curr Med Chem 25:65-74

Publisher's note Springer Nature remains neutral with regard to jurisdictional claims in published maps and institutional affiliations. 